\title{
Concurrentie en efficiëntie in het bankwezen
}

\section{Jaap A. Bikker en Jaap W.B. Bos}

SAMENVATTING Dit artikel gaat in op de aard en mate van concurrentie op de Nederlandse bankenmarkt en de efficiëntie van Nederlandse banken. Vervolgens worden de uitkomsten voor Nederland vergeleken met bancaire concurrentie en efficiëntie in andere landen, in het bijzonder die in Europa. Op vrijwel alle bankenmarkten van industriële landen is sprake van relatief sterke concurrentie, maar in de meeste gevallen wordt geen volledige mededinging gevonden. Overigens blijkt de mate van concurrentie minder sterk op lokale, op retail georiënteerde markten en veel sterker op internationale, op 'wholesale' gerichte markten. De bancaire deelmarkten in Nederland zijn niet minder concurrerend dan gemiddeld genomen elders het geval is. De uitkomsten lijken te duiden op een mate van concurrentie die bankklanten voldoende zekerheid geeft op redelijke prijzen en dienstverlening, terwijl banken in staat zijn voldoende winst te genereren om hun financiële gezondheid te kunnen handhaven, zodat geen direct gevaar voor financiële stabiliteit dreigt. Schattingen van kostenefficiënties van Nederlandse banken suggereren dat op kosten gemiddeld nog circa 5\% kan worden bespaard. Berekening van winstefficiënties laat zien dat daar nog forse vooruitgang mogelijk is, die deels door relatief kleine kostenreducties kan worden gerealiseerd. Grote Nederlandse banken steken gemiddeld genomen in termen van efficiëntie goed af bij hun grote concurrenten uit andere landen. De efficiëntie van banken in Nederland en elders is in het afgelopen decennium significant verbeterd. Daarbij dient te worden aangetekend dat het voor een bank moeilijk is om een hoge efficiëntie ook over de grens te realiseren. Het is aannemelijk dat deregulering en financiële en monetaire integratie in de Europese Unie verder aan concurrentieverbetering en efficiëntiewinst hebben bijgedragen. Dit artikel richt zich met name op bankiers alsmede op beleidsmakers, toezichthouders en wetenschappers die zich bezighouden met de financiële sector.

\section{Inleiding}

Liberalisatie en harmonisatie in de Europese Unie hebben het afgelopen decennium een sterke invloed uitgeoefend op de financiële omgeving, waarin Europese banken opereren. Het ontstaan van grote en transparante kapitaalmarkten voor de euro heeft concurrentie in het Europese bankwezen bevorderd. De comparatieve voordelen van banken op hun binnenlandse markten bij begeleiding van emissies van vreemd en eigen kapitaal en bemiddeling bij beleggen zijn sterk afgenomen sinds de euro nationale valuta heeft vervangen. Deze bijdragen aan de internationale integratie hebben, tezamen met de toetreding van nieuwe typen concurrenten, de buitenlandse concurrentie van banken in het EMU-gebied versterkt. Dit heeft banken gedwongen efficiënter te worden en heeft geleid tot consolidatie en rationalisatie van het bankwezen.

Concurrentie op de bankenmarkt en efficiëntie van banken zijn belangrijke factoren voor de prestaties en de financiële gezondheid van banken en voor de welvaart van consumenten en bedrijven. Deze positieve effecten zijn sterk en duidelijk voorzover het efficiëntie betreft. Inefficiëntie is immers verspilling en dat gaat samen met of lagere winsten of hogere banktarieven óf beide. De rol van concurrentie ligt meer gecompliceerd. Voor klanten van banken is concurrentie voordelig, omdat het banktarieven laag houdt en de serviceverlening hoog. Concurrentie dwingt

Dr. J.A. Bikker en Dr. J.W.B. Bos zijn senior beleidsmedewerker/onderzoeker bij De Nederlandsche Bank, Directoraat Toezicht, Sectie Strategie. De in dit artikel geuite opvattingen zijn die van de auteurs en vertegenwoordigen niet noodzakelijkerwijs het standpunt van De Nederlandsche Bank. De auteurs danken Dr. M. Gelderman voor nuttig commentaar. 
banken ook om efficiënter te worden. Al te sterke concurrentie zou sommige individuele banken echter dichter bij solvabiliteitsproblemen kunnen brengen en zo ook de financiële stabiliteit kunnen bedreigen. Overigens zou het niet terecht zijn te concluderen dat concurrentie nadelig doorwerkt op de financiële stabiliteit (voor een overzicht, zie Canoy et al., 2001, en Bikker en Wesseling, 2003). In een tegen concurrentie afgeschermde markt kunnen ongezonde ontwikkelingen soms immers langer voortwoekeren en uiteindelijk een grotere bedreiging van de financiële stabiliteit vormen. Sommige studies wijzen op de risico's voor financiële stabiliteit, die juist optreden op geconsolideerde markten met minder concurrentie, aangevend dat consolidatie erger kan zijn dan sterke concurrentie (Carletti en Hartmann, 2002; Caminal en Matutes, 2002). Beck et al. (2003) vinden op grond van analyse van gegevens van een groot aantal landen over een groot aantal jaren juist dat crises minder waarschijnlijk zijn naarmate het bankwezen meer geconcentreerd is. Wel bevestigen zij dat het gevaar van crises minder groot is naarmate een land minder restricties op concurrentie kent en betere instellingen heeft voor de bevordering van concurrentie. De Groep van Tien (2001) concludeert dan ook dat het van specifieke gevallen en omstandigheden afhangt of een verandering in concurrentie of concentratie samengaat met meer of minder stabiliteit. Al met al lijkt gezonde concurrentie goed te kunnen samengaan met gezonde banken en financiële stabiliteit.

Dit artikel gaat nader in op wat wij weten van concurrentie op de bankenmarkt en efficiëntie van banken. Dit weten is geen vanzelfsprekende zaak, omdat concurrentie en efficiëntie niet direct kunnen worden waargenomen. Het hiernavolgende presenteert uitkomsten van onderzoek dat gebaseerd is op de meest succesvolle meetmethoden op dit gebied. Daarbij moet worden benadrukt dat de uitkomsten met een bepaalde mate van onzekerheid zijn omgeven. De nadruk in dit artikel ligt op de wijze en mate van concurrentie op de Nederlandse bankenmarkt en de efficiëntie van Nederlandse banken, alsmede de vergelijking hiervan met bancaire concurrentie en efficiëntie in andere landen, in het bijzonder die in Europa. Paragrafen 2 en 3 bespreken hoe onderzoekers meer over concurrentie te weten komen en wat daarvan de uitkomsten zijn. Paragraaf 4 gaat in op wat we weten over efficiëntie in Nederland. Paragraaf 5 maakt een vergelijking tussen grote, internationale banken in Nederland en vergelijkbare banken in andere landen. Paragraaf 6 bespreekt de invloed van verschillende marktomstandigheden en overige institutionele condities op efficiëntie van ban- ken in Nederland en diverse andere landen. Paragraaf 7 analyseert de ontwikkeling van concurrentie en efficiëntie over de tijd. Het artikel sluit af met conclusies.

\section{Marktmacht van banken:} de structuur-gedrag-prestatie hypothese

Om meer over marktmacht te weten wordt in de wetenschappelijke literatuur veel gebruikgemaakt van de zogeheten structuur-gedrag-prestatie (SGP)-hypothese (zie Molyneux et al., 1996; Punt en Van Rooij, 2003). Volgens deze hypothese beïnvloedt de structuur van de bankenmarkt (bijvoorbeeld het aantal banken, de concentratie daarvan en de toetredingsmogelijkheden) in belangrijke mate het gedrag van banken (bijvoorbeeld door middel van prijsafspraken), wat vervolgens het presteren van banken verklaart (bijvoorbeeld bovenmatige winst maken). Bij het in de praktijk testen van de SGP-hypothese door middel van een regressiemodel wordt de winst van banken derhalve verklaard door één of meer kenmerken van de marktstructuur (bijvoorbeeld een indicator voor de concentratie), alsmede door een aantal bankspecifieke variabelen (bijvoorbeeld type bank, risicoprofiel en grootte). Een positief, significant effect van de marktstructuurvariabelen op de winst duidt dan op de aanwezigheid van marktmacht. Een alternatieve verklaring voor zo'n positief effect wordt gegeven door de zogenaamde Efficiëntie-hypothese. Volgens deze hypothese leiden bestaande verschillen in bancaire efficiëntie tot zowel verschillen in marktaandeel (en dus verandering in de marktstructuur) als verschillen in prestatie. Marktmacht is dan niet oorzaak maar gevolg van winstgevendheid. Om foutieve interpretatie te voorkomen moeten beide hypotheses gelijktijdig worden getest. Daartoe worden in het regressiemodel ook efficiëntiemaatstaven opgenomen (Berger en Hannan, 1993; Bos, 2003).

Het regressiemodel om de SGP-hypothese te toetsen is op talrijke verschillende manieren toegepast. In veel gevallen wordt marktmacht aangetoond doordat blijkt dat de winst toeneemt met de concentratiegraad, waarmee volledige mededinging wordt verworpen. Elke methode heeft naast voordelen ook nadelen en dat geldt dan ook voor de SGP-hypothese. Een voordeel van de gehanteerde toets op de SGPhypothese is het feit dat er geen marktprijzen nodig zijn om het regressiemodel te schatten. Omdat marktprijzen in de praktijk juist bij banken moeilijk te meten zijn, is de SGP-toets een aantrekkelijk alternatief. Dat verklaart de aanhoudende populariteit van het regressiemodel voor deze toets. Een nadeel is dat 
bij bevestiging van de SGP-hypothese niet kan worden gemeten hoe sterk die marktmacht is. Daarom is het zinvol ook andere bronnen van informatie over concurrentie te benutten.

\section{Marktmacht van banken: het Panzar-Rosse model}

Een alternatieve methode voor het meten van marktmacht is het Panzar-Rosse model, waarin de renteinkomsten van een bank onder meer afhangen van de inputprijzen (Bikker en Groeneveld, 2000; Bikker, 2004). Deze afhankelijkheid wordt beschreven met de parameter $H$, de som van de inputprijselasticiteiten. Hiermee kan onderscheid worden gemaakt tussen verschillende vormen van marktstructuur. De eerste is volledige mededinging, een marktvorm waarin de rente-inkomsten evenredig omhoog of omlaag gaan met de inputprijzen (zodat $H$ één is). Er is immers door de concurrentie geen overwinst: stijging van de inputprijzen moet volledig worden doorberekend in de outputprijs, anders wordt verlies geleden, terwijl daling van de inputprijzen in de outputprijs moet worden gevolgd, want dat doet de concurrentie ook. De tweede marktvorm is monopolie of volledige samenwerking, waarin de bank of het kartel die prijzen kiest die de winst maximaal maken. Er is dan geen of een negatieve relatie tussen outputprijzen en inputprijzen (zodat $H$ nul of negatief is): stijging tast de monopoliewinst aan, terwijl daling de opbrengst vergroot. De derde marktvorm, monopolistische concurrentie, komt vooral in de financiële sfeer veel voor.
Doordat producten en diensten op kleine onderdelen van elkaar verschillen, kan de concurrentie wat worden getemperd. Bij oligopolie of monopolistische concurrentie is er ook samenhang tussen input- en outputprijzen, maar minder dan evenredig $(0<H<1)$. $H$ is dan een maat van concurrentie.

Tabel 1 presenteert schattingen van $H$ voor een aantal landen op basis van drie inputprijzen: de financieringsrente, arbeidskosten en overige kosten. Tevens toont de tabel het gemiddelde van $H$ voor 23 OESOlanden. De eerste kolom geeft schattingen voor alle banken. Opvallend is dat in alle 23 landen voor de bankenmarkt als geheel geldt dat er enerzijds geen sprake is van een monopolie of volledig kartel èn anderzijds dat er geen volledige mededinging bestaat. Kennelijk worden alle onderzochte nationale bankenmarkten getypeerd met oligopolie of monopolistische concurrentie. Deze uitkomst spoort met die uit de SGP-analyse, waarin gewoonlijk ook een bepaalde mate van marktmacht werd gevonden (Bos, 2003). De concurrentiegraad van de Nederlandse banken is met 0,75 net iets hoger dan het gemiddelde $(0,70)$. De concurrentie in Europa $(0,73)$ blijkt hoger te zijn dan die buiten Europa $(0,64)$. Opvallend is dat Duitsland en de Angelsaksische landen in dat opzicht ook achterblijven. Duitsland en de Verenigde Staten hebben een nog niet geconsolideerde bankenmarkt met erg veel kleine banken, die zich op de lokale markt richten waar ze in beperkte mate concurrentie ondervinden. Dit weerspiegelt zich in lage gemiddelde concurrentiescores van, respectievelijk, 0,63 en 0,56.

Tabel 1. Schattingsresultaten voor $\boldsymbol{H}$ voor banken van verschillende grootte

\begin{tabular}{|c|c|c|c|c|}
\hline & Alle banken & Kleine banken & Middelgrote banken & Grote banken \\
\hline Nederland & 0,75 & 0,74 & 0,87 & 0,95 \\
\hline België & 0,89 & 0,95 & 0,88 & 0,88 \\
\hline Duitsland & 0,63 & 0,59 & 0,70 & 1,03 \\
\hline Frankrijk & 0,70 & 0,59 & 0,79 & 0,89 \\
\hline Groot-Brittannië & 0,64 & 0,41 & 0,85 & 1,20 \\
\hline VS & 0,56 & 0,62 & 0,54 & 0,72 \\
\hline Gemiddelde 23 OESO-landen & 0,70 & 0,65 & 0,75 & 0,86 \\
\hline Gemiddelde Europa & 0,73 & 0,70 & 0,79 & 0,91 \\
\hline Gemiddelde niet-Europa & 0,64 & 0,41 & 0,64 & 0,71 \\
\hline
\end{tabular}

Bron: Bikker en Haaf (2002).

Toelichting: De gegevens hebben betrekking op $1997^{* *}$. 
De bankenmarkt bestaat uit diverse deelmarkten, te onderscheiden naar afnemer (particuliere consumenten, midden- en kleinbedrijf en grote, internationale bedrijven), product (sparen, hypothecair krediet, bedrijfskrediet, dienstverlening op de kapitaalmark) en regio (lokaal, nationaal en internationaal). Tabel 1 doet een stap in de richting van segmentatie van de bankenmarkt naar deelmarkten door onderscheid te maken tussen kleine banken die meer lokaal werken en zich richten op de retailmarkt, grote banken die internationaal werken en zich meer richten op grote bedrijven, en middelgrote banken die een tussenpositie innemen (kolommen 2, 3 en 4). Uiteraard wordt op deze wijze slechts bij benadering inzicht verkregen in de concurrentie op de deelmarkten.

Overeenkomstig de verwachting blijkt dat kleine banken veelal minder concurrentie ondervinden: de mededinging op lokale markten en in de retailsector is kennelijk geringer (de $H$-waarde is gemiddeld 0,65 ). In de meeste landen wordt monopolistische concurrentie gevonden, terwijl in enkele landen volledige mededinging waarschijnlijk is. Grote banken opereren in een beduidend concurrerender omgeving: de tegenpartijen zijn machtiger en buitenlandse banken concurreren mee (de $H$-waarde is gemiddeld 0,86 ). In veel meer landen duiden de uitkomsten hier op volledige mededinging. Een waarde van $H$ net wat groter dan 1 - zoals voor grote banken in Groot Brittannië - kan duiden op een meetfout of op een aparte marktvorm waarbij banken bij het zetten van hun prijzen strategisch handelen door rekening te houden met de manier waarop ze verwachten dat andere banken op die prijzen zullen reageren.

Middelgrote banken nemen ook in termen van concurrentie een tussenpositie in. Op de drie Nederlandse deelmarkten is de concurrentie duidelijk wat groter dan gemiddeld genomen in andere landen het geval is.

\section{Efficiëntie en marktmacht}

In een poging meer grip te krijgen op het meten van de prestaties van banken wordt in toenemende mate ook getracht naast de werkelijke prestaties (winst) ook de potentiële prestaties (haalbare winst) te analyseren. Een belangrijke gedachte hierbij is dat in een - voor consumenten ideale - situatie waarin van volledige mededinging sprake is, banken gedwongen zijn om hun kosten zoveel mogelijk te minimaliseren, ten einde niet uit de markt te worden gedreven. Wanneer echter sprake is van marktmacht, dan kunnen banken mogelijk meer winst behalen zonder dat ze hiervoor hun kosten hoeven te drukken. Banken realiseren deze overwinsten dan door prijsverhogingen. De mate waarin ze door middel van deze prijsverhogingen hun winsten kunnen verhogen, hangt af van de reactie van de concurrentie, maar ook van de reactie van de consument. Daarmee wordt duidelijk dat het presteren van banken in een bepaalde markt deels verklaard kan worden door interne factoren zoals goed management, maar deels ook door marktomstandigheden. Omdat ze elkaar beïnvloeden, is het dan ook vaak moeilijk om management en marktomstandigheden elk afzonderlijk te meten.

Bij onderzoek naar de mate waarin banken, gegeven hun eigen (al dan niet optimale) keuzes in staat zijn hun kosten te minimaliseren of hun winst te maximaliseren, wordt in toenemende mate gebruikgemaakt van efficiëntiemaatstaven. De standaard micro-economische theorie leert dat wanneer een markt wordt gekenmerkt door volledige mededinging, geen enkele bank in staat zal zijn bovenmatige winsten te behalen. Meer in het algemeen zal een bank - in afwezigheid van overige factoren die marktmacht kunnen veroorzaken - alleen dan meer dan gemiddeld winstefficiënt zijn, indien zij ook meer dan gemiddeld kostenefficiënt is. Indien sprake is van marktmacht, is een bank niet langer prijsnemer en kan zij door het verhogen van haar prijs haar winst doen toenemen (hogere winstefficiëntie), zonder dat zij haar kosten behoeft te verlagen (gelijkblijvende kostenefficiëntie). Die marktmacht kan veroorzaakt zijn door monopolie of samenwerking (oligopolie), of door schaalvoordelen, waardoor grote banken bij eenzelfde gemiddeld kostenniveau meer kunnen produceren dan kleine banken, of door productdifferentiatie.

Het is dus mogelijk een bankenmarkt te kenschetsen door het presteren van de betrokken banken te meten. Onder presteren wordt dan verstaan het relatief vermogen van banken om hun kosten te minimaliseren of hun winst te maximaliseren. Hierbij worden de kosten of winst van een bank vergeleken met die van de best presterende bank van gelijke grootte (zodat het effect van schaalvergroting is geëlimineerd), daarbij rekening houdend met verschillen in de inputprijzen en in de samenstelling van de productie. Deze prestatieverschillen worden aangeduid met X-efficiëntie en kunnen worden toegeschreven aan de kwaliteit van het bankmanagement.

Bos en Kool (2002) hebben een dergelijke meting uitgevoerd voor de Nederlandse banken, waarbij zowel kosten- als winstefficiënties zijn bepaald. Kosten- 
efficiëntie beschouwt alleen de kosten, terwijl winstefficiëntie kijkt naar zowel kosten als maximalisatie van de omzet. Ter toelichting zij vermeld dat de best presterende bank volledig efficiënt heet en een efficiëntiescore van 1 haalt, terwijl een score van 0 totale inefficiëntie zou betekenen. De gemiddelde kostenefficiëntie van Nederlandse banken blijkt 0,95 te zijn, wat betekent dat banken hun kosten bij de huidige productie door beter management gemiddeld nog met circa 5\% zouden kunnen drukken ${ }^{1}$. Ze zouden dan uitkomen op het lage kostenniveau van de best mogelijke presterende banken. Bij een totaal kostenniveau van Nederlandse banken van circa $€ 34$ miljard per jaar impliceert 5\% altijd nog € 1,7 miljard. De winstefficiëntie van Nederlandse banken is met 0,7 een stuk lager dan de kostenefficiëntie. Banken zouden hun winst bij de huidige productie in theorie door 'ideaal' management gemiddeld nog met enkele tientallen procenten kunnen vergroten. Bij een totaal winstniveau van Nederlandse banken van circa $€ 7$ miljard per jaar zou $30 \%$ een bedrag van bijna $€ 2$ miljard impliceren. Reductie in kosten ter grootte van $€ 1,7$ miljard zou volgens deze resultaten het grootste deel van de winstinefficiëntie kunnen wegnemen. Daarnaast slagen sommige banken er kennelijk beter in dan andere om gebruik te maken van marktmacht en aldus prijzen en winst te verhogen. Overigens variëren vooral de winsten van jaar tot jaar, onder invloed van de algemene conjunctuur en ontwikkelingen op de financiële markten, zodat deze vertaling van efficiëntiescores naar bedragen in euro's ook van jaar tot jaar kan verschillen.

Bij het onderzoek naar efficiëntie van Nederlandse banken is onderscheid gemaakt naar drie bankcategorieën: kleine en grote algemene banken en gespecialiseerde banken. In termen van kostenefficiëntie blijken de drie groepen even goed te presteren. In termen van winstefficiëntie lopen de prestaties echter wat uiteen: kleine, algemene banken zijn significant minder winstefficiënt dan de grote, algemene banken en de gespecialiseerde banken, al is het verschil niet zo groot. Dit uiteenlopen kan worden verklaard uit het gegeven dat grote en gespecialiseerde banken dankzij hun for-

\section{Figuur 1. Efficiëntie van grote banken vergeleken}

\section{Winstefficiëntie}

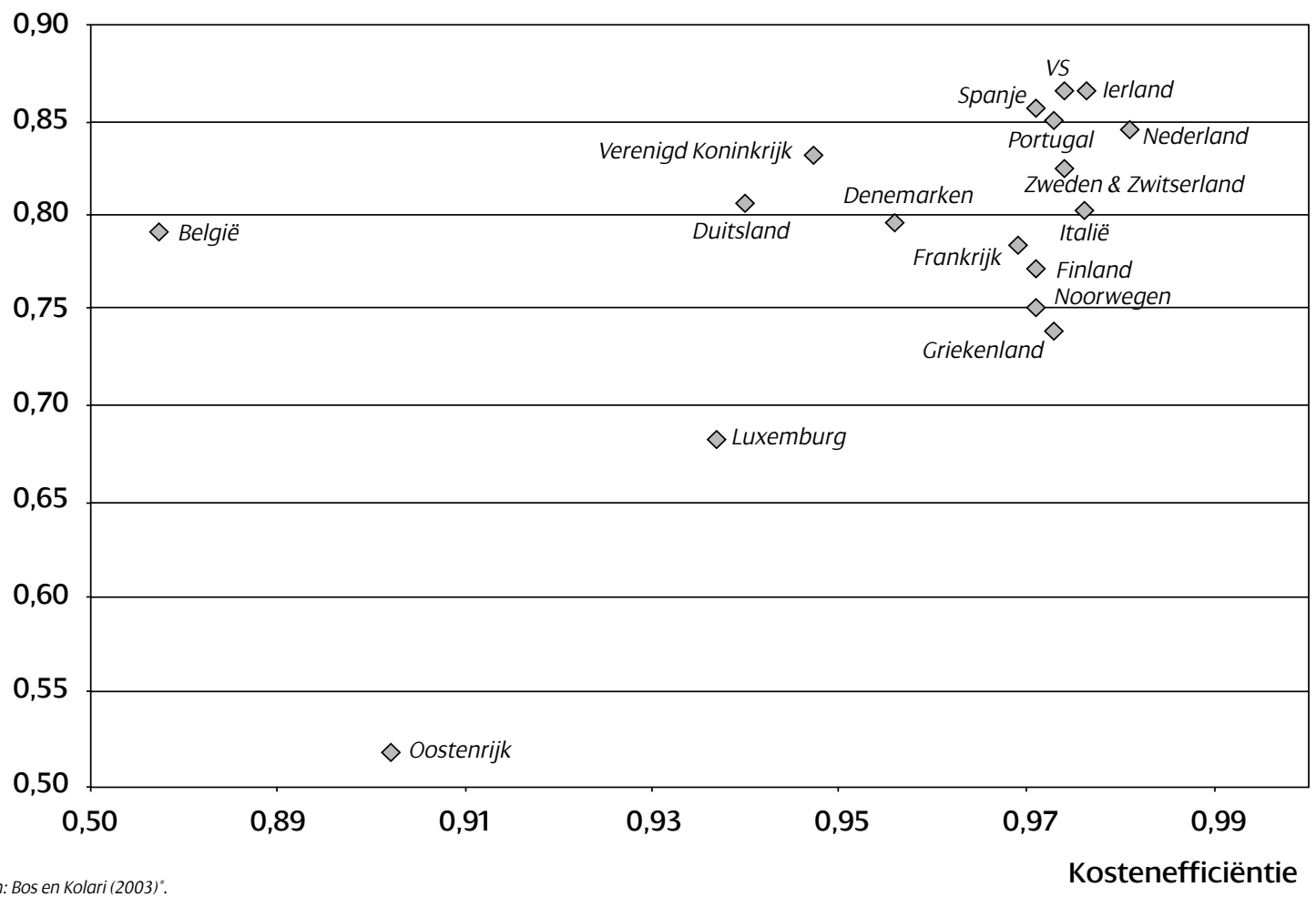

"Gegevens voor onafhankelijke instellingen over de periode 1995-1999. Gegevens voor Amerikaanse banken afkomstig uit Call Reports van de Federal Reserve. 
maat, reikwijdte of kennis over wat meer marktmacht beschikken, waardoor ze meer dan gemiddeld winstefficiënt kunnen zijn, zonder wat betreft kosten in een betere positie te verkeren.

\section{Efficiëntie van grote banken internationaal vergeleken}

De vraag rijst hoe de Nederlandse banken zich verhouden tot hun concurrenten in Europa en de Verenigde Staten. Mede door de hoge vereisten aan de gegevens en conceptuele problemen is op het gebied van internationaal vergelijken nog relatief weinig onderzoek gedaan; enkele uitzonderingen zijn Altunbas et al. (2000) en Bikker (2001, 2002). Net als voor Nederland is ook voor andere landen een veel gevonden resultaat dat verschillen in kostenefficiëntie vele malen kleiner zijn dan verschillen in winstefficiëntie (Berger et al., 1993; Berger en Humphrey, 1997). Daarbij dient echter wel, zoals hierboven beschreven, te worden opgemerkt dat een relatief kleine reductie in kosten een groot deel van de winstinefficiëntie weg kan nemen. Het verschil tussen kosten- en winstefficiëntie kan verder worden verklaard door het feit dat winstefficiëntie - veel meer dan kostenefficiëntie - wordt bepaald door de marktomstandigheden waarin een instelling opereert. De prijszetting die een bank kan hanteren werkt immers direct door op de winstmaximalisatie. Daarnaast is winst een meer beweeglijke grootheid dan kosten, waardoor procentuele verschillen in winst en winstefficiëntie tussen banken groter zijn dan die bij kosten.

In deze paragraaf worden grote Nederlandse banken vergeleken met hun concurrenten in het buitenland. $\mathrm{Er}$ is gekozen voor grote banken omdat deze door de internationale concurrentie onderling meer vergelijkbaar zijn dan bijvoorbeeld de kleine banken. Figuur 1 toont per land - met totale activa van banken gewogen - gemiddelde efficiëntiescores van deze grote banken met wereldwijde activiteiten. Absolute uitblinkers blijken de grote banken in Ierland, Nederland en de Verenigde Staten, zowel wat betreft kosten- als winstefficiëntie. De lage scores voor Luxemburg en Oostenrijk zijn mogelijk minder betrouwbaar, gezien het geringe aantal grote banken in deze landen.

Figuur 1 laat duidelijk zien dat winstefficiëntie met een variatie van 0,52 tot 0,87 een veel grotere spreiding heeft dan de kostenefficiëntie die uiteenloopt van 0,88 tot 0,98 . Een belangrijke oorzaak van het verschil in spreiding ligt in de per land uiteenlopende markt- omstandigheden. Voorzover winstefficiëntie wordt bepaald door lokale marktomstandigheden, zoals het bestaan van marktmacht of institutionele condities, valt niet te verwachten dat banken deze efficiëntie bij een gang naar het buitenland als het ware volledig mee kunnen nemen. Om die reden zal een Nederlandse of Ierse bank die in Duitsland, België of Oostenrijk gaat opereren (bijvoorbeeld door middel van een overname) waarschijnlijk meer moeite hebben met het genereren van de in het thuisland gebruikelijke winst.

\section{Marktomstandigheden in Nederland en elders}

Bij het internationaal vergelijken van efficiëntie is het daarom van groot belang te weten in hoeverre marktcondities en institutionele omstandigheden van land tot land verschillen. Deze bepalen namelijk per land voor elke grootte van een bank de maximale efficiëntie, of in vakjargon, de efficiëntiegrens. Immers, wanneer voor ieder land afzonderlijk een efficiëntiegrens wordt geschat, bepaald door de best presterende banken, dan kunnen de resulterende efficiëntiewaarden weliswaar binnen een land worden vergeleken, maar niet tussen de landen. De efficiëntie is immers de afstand tot de best presterende banken, en die verschillen van land tot land. Wanneer een optimale efficiëntiegrens voor een groep banken uit verschillende landen gezamenlijk wordt geschat, bepaald door de internationaal gezien best presterende banken, dan kunnen de efficiëntiewaarden wel worden vergeleken. Probleem is echter dat de efficiëntiewaarden dan mogelijk vertekend zijn, doordat geen rekening is gehouden met land- of marktspecifieke factoren. Hierdoor kunnen banken in een land bijzonder inefficiënt lijken doordat ze vergeleken worden met een realistisch gezien onhaalbare optimale grens. Dit probleem is op te lossen met behulp van een schattingsmethode, waarbij een zogenaamde metagrens wordt geconstrueerd met behulp van de landspecifieke efficiëntiegrenzen (nationale best presterende banken), zie Bos en Schmiedel (2003). Hierdoor worden de landspecifieke eigenschappen behouden, terwijl toch vergelijkbare efficiëntiescores worden verkregen.

In figuur 2 worden opnieuw banken in een aantal landen vergeleken. In tegenstelling tot figuur 1, waar alleen voor grote banken (inclusief banken in de VS) één grens werd geschat, wordt hier voor alle banken kosten- en winstefficiëntie geschat. Figuur 2 demonstreert hoe de relatieve kosten- en winstefficiënties veranderen indien - in plaats van (zoals in figuur 1) een gezamenlijke grens - een zogeheten metagrens wordt geschat. Ten eerste valt op dat in vrijwel elk 
land de schatting van de gemiddelde kosten- en winstefficiëntie toeneemt zodra de gezamenlijke grens wordt vervangen door de metagrens. Dit is het gevolg van het feit dat landspecifieke grenzen kennelijk sterk uiteenlopen. Grote uitzondering in dit patroon van toenemende efficiënties is Duitsland, waar zowel de kosten- als winstefficiëntie afneemt. Dit is des te opvallender aangezien beide types efficiënties, maar vooral winstefficiëntie, in de uitgangspositie reeds laag waren. Uit de analyse blijkt dan ook dat zelfs de meest efficiënte Duitse banken relatief inefficiënt zijn in vergelijking met andere Europese banken. Deze lage efficiënties spelen uiteraard ook een rol in de recent opgelaaide discussie over de efficiëntie van het Duitse bankwezen. Een andere opvallende uitkomst is de bijzonder sterke toename in zowel kosten- als winstefficiëntie in het Nederlandse bankwezen. Dit resultaat duidt erop dat de voor Nederlandse banken geldende efficiëntiegrenzen nog altijd sterk verschillen van wat voor andere Europese landen geldt. Hierdoor wordt de efficiëntie van Nederlandse banken waarschijnlijk (meer dan in veel andere landen) onderschat, wanneer wordt gemeten ten opzichte van een gezamenlijke grens, in plaats van een metagrens.
De uitkomst van figuur 2 biedt ook een verklaring van het vrijwel ontbreken van grensoverschrijdende bankfusies en overnames in de EU. Uit deze resultaten blijkt namelijk dat het kennelijk moeilijk is om in eigen land geboekt succes in het buitenland te herhalen. Ook valt op dat succesvolle kostenbeheersing niet automatisch tot meer winstefficiëntie, en daarmee tot een hogere winst, leidt. Zo zijn Belgische banken gemiddeld het meest kostenefficiënt, maar weten zij relatief minder efficiënt winst te realiseren dan bijvoorbeeld hun Nederlandse of Britse concurrenten. Het is niet duidelijk wat het bestaan van deze verschillen verklaart. Zo kan het zijn dat de gemiddelde kwaliteit van het management per land significant verschilt. Maar ook is het mogelijk dat de verschillen tussen landen verdere integratie op dit gebied vooralsnog niet toestaan.

\section{Toename concurrentie en efficiëntie over de tijd}

Vaak wordt gesteld dat deregulering, liberalisering en nieuwe technologie de nationale en internationale concurrentie hebben versterkt. In Europa kwam daar de voortschrijdende financiële en monetaire integratie

Figuur 2. Van gezamenlijke grens naar metagrens

\section{Winstefficiëntie}

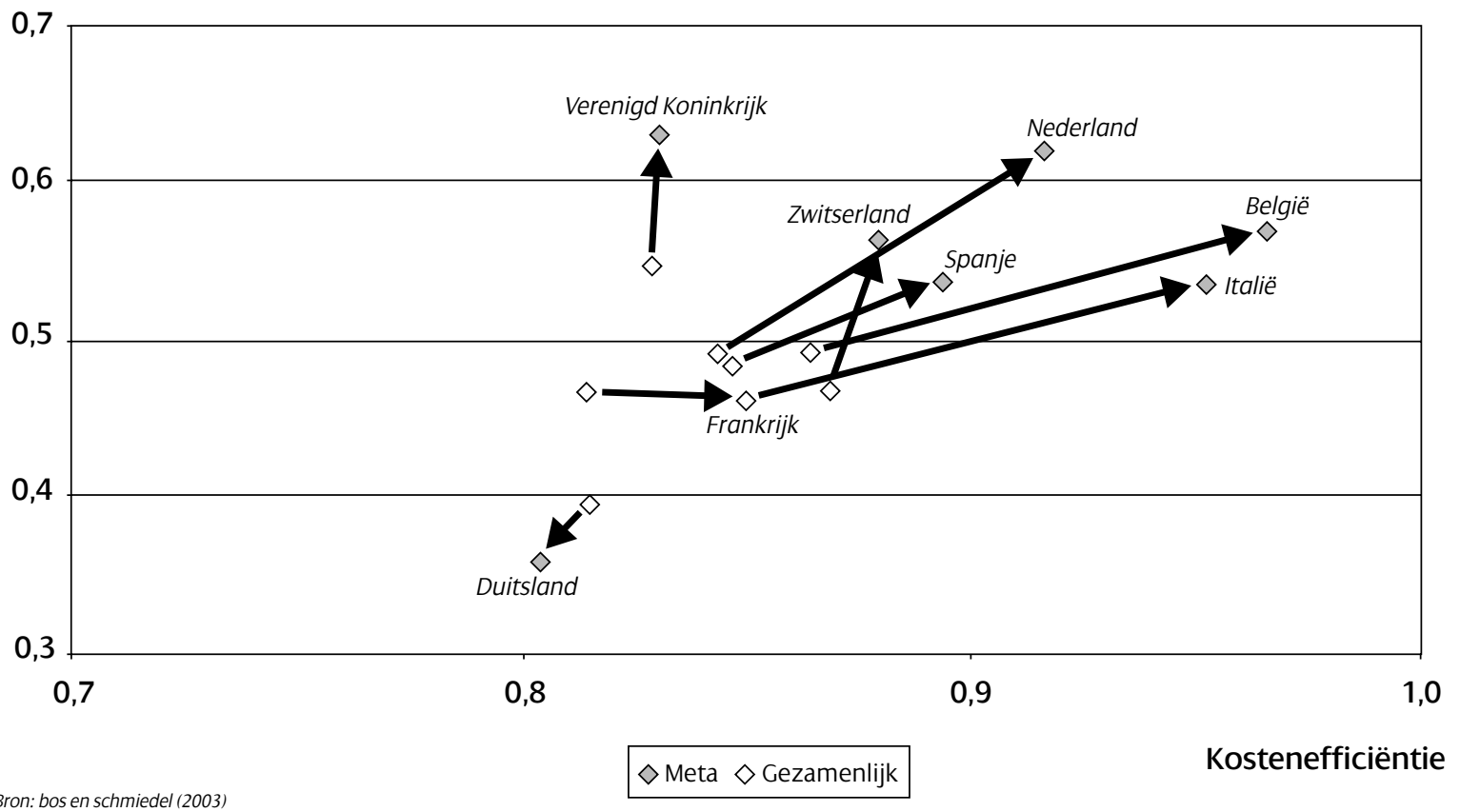

Toelichting: De gegevens hebben betrekking op 1993-2000. 
nog bij. De toenemende concurrentie dwingt banken vervolgens om steeds efficiënter te worden. De vraag rijst of deze veranderingen ook in de schattingen van concurrentie en efficiëntie zijn terug te vinden.

In deze paragraaf meten we de gevolgen van deze veranderingen op twee manieren. Eerst vergelijken we de $H$-maatstaven in 1997 (zie de berekeningen van tabel 1 op p. 171) met $H$-maatstaven voor een eerdere periode, rond 1991. Gezien de grote veranderingen in de bankenmarkt gedurende het afgelopen decennium zou een beduidende toename van de concurrentie mogen worden verwacht. Hierbij valt op dat de mate van concurrentie in veel landen en deelmarken inderdaad wel wat is toegenomen, maar - uitgedrukt in de $H$-maatstaf - slechts in geringe mate. Wellicht slagen banken erin om de toename in de concurrentiedruk enigszins te verminderen, bijvoorbeeld door productdifferentiatie, wat zou sporen met de in tabel 1 waargenomen monopolistische concurrentie in de meeste landen.

\begin{tabular}{lcc}
\hline Tabel 2. Verandering in efficiëntie over de tijd \\
& Aantal banken & Efficiëntie \\
\hline 1990 & 31 & 0,563 \\
1991 & 52 & 0,543 \\
1992 & 220 & 0,563 \\
1993 & 364 & 0,564 \\
1994 & 515 & 0,590 \\
1995 & 1126 & 0,653 \\
1996 & 2135 & 0,733 \\
1997 & 1907 & 0,739 \\
Bron: Bikker (2002). & & \\
\hline
\end{tabular}

Vervolgens vergelijken we over het tijdvak 1990-1997 de jaarlijkse veranderingen in kostenefficiëntie. Toegenomen aandacht voor efficiëntie van banken, mede onder druk van sterkere concurrentie, doen verwachten dat deze over de tijd zal zijn toegenomen. Dat blijkt inderdaad het geval te zijn. Tabel 2 laat zien dat de kostenefficiëntie van Nederlandse en Europese banken over het tijdvak 1990-1997 systematisch van jaar op jaar is toegenomen. In 1991 is er nog sprake van een forse achterstand in efficiëntie op de VS. Echter, in totaal blijkt de inefficiëntie in zeven jaar met gemiddeld circa $45 \%$ te zijn afgenomen, waardoor deze achterstand op de VS behoorlijk is gereduceerd. Dit suggereert een belangrijke bijdrage van deregulering en economische en financiële integratie in Europa op de welvaart van zowel klanten als eigenaars van banken. Omdat slechts een beperkte toename in concurrentie kan worden aangetoond, is concurrentie kennelijk niet de dwingende kracht achter efficiëntieverbetering geweest. Het ligt daarom voor de hand dat ook andere factoren daaraan hebben bijgedragen, zoals toegenomen aandacht voor winstgevendheid of 'shareholder value'.

\section{Conclusies}

De activiteiten en producten van banken ondergaan een metamorfose door de technologische vooruitgang in informatica en ontwikkelingen in financiële technieken, terwijl banken onder druk staan van het veranderende economische en financiële klimaat. De informatietechnologie heeft bijgedragen tot internationalisering van geld- en kapitaalmarkten, de ontwikkeling van nieuwe risicobeheertechnieken en de opkomst van nieuwe, complexe financiële producten en nieuwe afzetkanalen. De institutionele omstandigheden in Europa zijn ingrijpend veranderd door onder meer de tweede EU-bankenrichtlijn (één paspoort voor de hele EU) en door de oprichting van de EMU met haar nieuwe gemeenschappelijke munt. Dit alles heeft bijgedragen aan toenemende nationale en internationale concurrentie, die banken dwingt om steeds efficiënter te worden.

Dit artikel schetst een beeld van de mate van concurrentie op de Nederlandse bankenmarkt en die in andere industriële landen en van de mate van winsten kostenefficiëntie van Nederlandse en Europese banken. Daarbij moet veiligheidshalve worden benadrukt dat de gevonden schattingen van concurrentie en efficiëntie met een bepaalde mate van onzekerheid zijn omgeven. De structuur-gedrag-prestatie hypothese veronderstelt dat banken een zekere marktmacht kennen en benutten. In lijn daarmee duidt de Panzar-Rosse methode op monopolistische concurrentie of oligopolie. Op vrijwel alle bankenmarkten is sprake van relatief sterke concurrentie maar vaak geen volledige mededinging. Overigens blijkt de mate van concurrentie minder sterk op lokale, op retail georiënteerde markten en veel sterker op internationale, op 'wholesale' gerichte markten. De Nederlandse deelmarkten zijn meer concurrerend dan gemiddeld genomen elders het geval is. Voorzover hieruit algemene conclusies kunnen worden getrokken, lijken de uitkomsten te duiden op een mate van concurrentie die bankklanten voldoende zekerheid geeft op redelijke prijzen en dienstverlening, terwijl banken in staat zijn voldoende winst te genereren om hun financiële 
gezondheid te kunnen handhaven, zodat geen direct gevaar voor financiële stabiliteit dreigt. Over de mate van concurrentie op deelmarkten, onderscheiden naar afnemer, product of regio, vallen op grond van deze uitkomsten geen gedetailleerde conclusies te trekken.

Schattingen van kostenefficiënties van Nederlandse banken brengen aan het licht dat aan kosten gemiddeld nog circa $5 \%$ valt te besparen. Deze conclusie geldt voor zowel kleine en grote algemene banken als gespecialiseerde banken. Berekening van winstefficiënties laat zien dat daar een nog verhoudingsgewijs forse vooruitgang mogelijk is, die deels door relatief kleine kostenreducties kan worden gerealiseerd. Grote Nederlandse banken steken gemiddeld in termen van efficiëntie goed af bij hun grote concurrenten in andere landen. Bovendien is de efficiëntie van banken in Nederland en andere Europese landen in het afgelopen decennium significant verbeterd, wat waarschijnlijk toe te schrijven is aan toenemende concurrentie en aandacht voor winstgevendheid. Het is aannemelijk dat deregulering en financiële en monetaire integratie in de Europese Unie aan deze concurrentieverbetering en efficiëntiewinst hebben bijgedragen.

\section{Literatuur}

Altunbas, Y., E.P.M. Gardener, P. Molyneux en B. Moore, (2000), Efficiency in European banking, in: European Economic Review, 45, pp. 1931-1955.

Beck, T., A. Demirgüc-Kunt en R. Levine, (2003), Bank concentration and crises, NBER Working Paper Series no. 9921, National Bureau of Economic Research, Cambridge, MA (http://www.nber. org/papers/w9921).

Berger, A.N. en T.H. Hannan, (1993), Using efficacy measures to distinguish among alternative explanations of the structure-performance relationship in banking, Board of Government of the Federal Reserve System Finance and Discussion Series 93-18.

Berger, A.N. en D.B. Humphrey, (1997), Efficiency of financial institutions: International survey and directions for future research, in: European Journal of Operations Research, 98, pp. 175-212.

Berger, A.N., W.C. Hunter en S.G. Timme, (1993), Efficiency of financial institutions: a review of research past, present and future, in: Journal of Banking \& Finance, 17, pp. 221-249.

Bikker, J.A. en J.M. Groeneveld, (2000), Competition and concentration in the EU banking industry, in: Kredit und Kapital, 33, pp. 62-98.

Bikker, J.A., (2001), Efficiency in the European banking industry: an exploratory analysis to rank countries, in: Cahiers Economiques de Bruxelles, 172, pp. 3-28.

Bikker, J.A., (2002), Efficiency and cost differences across countries in a unified European banking market, in: Kredit und Kapital, 35, pp. 344-380. Bikker, J.A., (2004), Competition and efficiency in a unified European banking market, Edward Elgar.

Bikker, J.A. en K. Haaf, (2002), Competition, concentration and their relationship: an empirical analysis of the banking industry, in: Journal of
Banking \& Finance, 26, pp. 2191-2214.

Bikker, J.A. en A.A.T. Wesseling, (2003), Intermediation, integration and internationalisation: a survey on banking in Europe, in: DNB Occasional Paper, vol. 1, no 3, De Nederlandsche Bank, Amsterdam.

Bos, J.W.B., (2003), Improving market power tests: does it matter for the Dutch banking market? in: Research Series Supervision 56, De Nederlandsche Bank, Amsterdam (www.dnb.nl).

Bos, J.W.B. en H. Schmiedel, (2003), Comparing efficiency in European banking: a meta-frontier approach, in: Research Series Supervision 57, De Nederlandsche Bank, Amsterdam (www.dnb.nl).

Bos, J.W.B. en J. Kolari, (2003), Large bank efficiency in Europe and the US: are there economic motivations for geographic expansion in financial services? in: Journal of Business, forthcoming.

Bos, J.W.B. en C.J.M. Kool, (2003), Bank size, specialization and efficiency: the Netherlands, 1992-2001, De Nederlandsche Bank, Amsterdam, mimeo.

Caminal, R. en C. Matutes, (2002), Market power and banking failures, in: International Journal of Industrial Organization, 20, pp. 1341-1361.

Canoy, M., M. van Dijk, J. Lemmen, R. de Mooij en J. Weigand, (2001), Competition and stability in banking, CPB Document no. 15, Central Planbureau, Den Haag (www.cpb.nl).

Carletti, E. en P. Hartmann, (2002), Competition and stability: what is special about banking? Working paper, 146, European Central Bank, Frankfurt am Main.

Groep van Tien, (2001), Report on Consolidation in the Financial Sector, Working Party on Financial Sector Consolidation, BIS, IMF en OECD (www.bis.org, www.imf.org en www.oecd.org).

Molyneux, P., Y. Altunbas en E. Gardener, (1996), Efficiency in European Banking, John Wiley \& Sons, New York.

Punt, L.W. en M.C.J. van Rooij, (2003), The profit-structure relationship and mergers in the European banking industry: an empirical assessment, in: Kredit und Kapital, 36, pp. 1-29.

\section{Noot}

1 Onder 'beter management' wordt verstaan het nemen van ideale beslissingen ter zake van bedrijfsstrategie, wijze van productie, et cetera. 